\title{
EIF2AK3 wt Allele
}

National Cancer Institute

\section{Source}

National Cancer Institute. EIF2AK3 wt Allele. NCI Thesaurus. Code C102828.

Human EIF2AK3 wild-type allele is located in the vicinity of $2 \mathrm{p} 12$ and is approximately 71 $\mathrm{kb}$ in length. This allele, which encodes eukaryotic translation initiation factor 2-alpha kinase 3 protein, is involved in both protein phosphorylation and the negative regulation of translation. Mutation of the gene is associated with Wolcott-Rallison syndrome. 